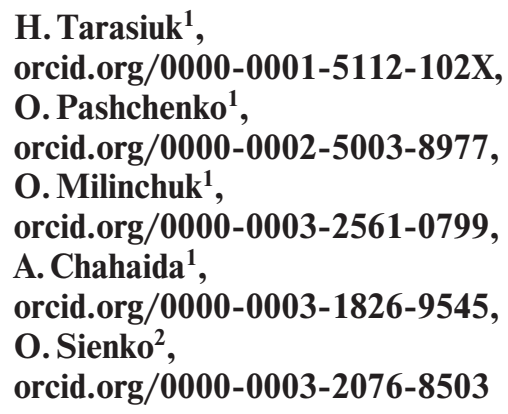

1 - Zhytomyr Polytechnic State University, Zhytomyr, Ukraine, e-mail: galinatar@ukr.net

2 - National University "Odessa Maritime Academy", Odesa, Ukraine, e-mail: o.sienko@onma.edu.ua

\title{
METHODICAL ASPECTS OF STABILITY DEVELOPMENT ASSESSMENT OF ENTERPRISES
}

Purpose. To clarify the definitions of concepts of "stability and stability of the enterprise". To identify the main factors that influence the sustainability of the enterprise. To form a system of indicators to assess the stability of enterprise development and to improve the methodology for this assessment on the basis of a balanced system of indicators.

Methodology. The study is based on the methods of analysis and synthesis, methods of comparison, absolute and relative values, abstraction, analogy, design and construction. To estimate the stability of development of the enterprises, at forecasting of possible algorithms of their development, methods of grouping, correlation-regression analysis, and variance are used.

Findings. The definition of the concepts of "stability and sustainability of the enterprise" is specified in the article. According to the authors, it is possible to identify these concepts, since the company cannot function separately from the environment. In addition, the stability and sustainability of the development of the enterprise imply a certain equilibrium of its state, or the ability to return to it, economic growth, i.e. the ability to accelerate the production and sales, to increase the efficiency of the usage of available resources, and so on. The main factors that influence the sustainability of the enterprise are identified, in particular: the changes in the system parameters, i.e. certain changes related to the components of the enterprise potential; the influence of environmental factors; the breach of communication within the enterprise itself, change in its structure. The strategic management of an enterprise based on sustainability of its development should take into account changes occurring in the business environment, evaluate the dynamics and make assumptions about the future state of the enterprise, possible pessimistic and optimistic scenarios of its development. The authors propose to evaluate the development of the enterprise on the basis of potential assessment, since the potential of the enterprise is the basis of its long-term development. The system of indicators of development stability estimation on the basis of the balanced system of indicators in the context of constituents of potential of enterprise is formed. The proposals for improvement of the methodology for assessing the stability of the development of the enterprise have been developed, and the methodology for assessing the stability of the development of the enterprise as a whole has been proposed.

Originality. The method for determining the integral indices of stability of enterprise development, which, unlike the existing ones, is based on the evaluation of development indicators in terms of potential components, is improved; the method of calculation of the integral index of stability of enterprise development as a whole is proposed.

Practical value. The methodological principles of the assessment of the stability of an industrial enterprise's development and the results of the research can be used for further scientific developments in this area, as well as in the practical activity of industrial enterprises for the evaluation of the intensity of their development. The assessment of the stability of the enterprise development on the basis of the established system of indicators provides an increase in the level of validity of management decisions to ensure the development of the enterprise by taking into account all aspects of the enterprise activity and developing a strategy for its development.

Keywords: production enterprise, stability of enterprise development, development strategy

Introduction. Ensuring effective strategic management in a market environment is a difficult problem, since being and operating in a dynamic environment, the company will experience the influence of many, not always foreseeable factors. However, an analysis that reveals common shortcomings in the work of the company does not always allow identifying precisely enough and objectively the specific causes of various negative phenomena that reduce the effectiveness of the enterprise, and therefore does not always allow determining what specific measures should be taken by managers to ensure a consistent, effective work. Therefore, when developing a development strategy, it is necessary to take into account the results of assessing the stability of the enterprise development.

Literature review. In the domestic and foreign literature there are many studies that address the problems of diagnostics and tools for assessing the sustainability of enterprise development in the context of environmental uncertainty. There is no clear methodology for determining the sustainability (stability) of an enterprise's development.

(C) Tarasiuk H., Pashchenko O., Milinchuk O., Chahaida A., Sienko O., 2020
In the framework of the study on economic sustainability of the enterprise, some scientists, in particular A.Zolotov, M. Pergament [1] do not distinguish the components by which a set of indicators of such assessment is subsequently formed.

A common method for determining economic sustainability is rapid analysis, which provides an analysis of the specialization of the company, its resource, financial and production activities. Based on the primary statistical information, a set of traditional indicators of the level of provision of basic production resources, financial status and efficiency of the enterprise's activity are calculated.

Sochenko V. proposed to supplement the method of rapid analysis of economic stability of the enterprise as an indicator of the level of economic stability. The content of this indicator reflects the share of revenue of the maximum volume of sales, which reimburses all costs for production and sales (critical sales volume) of products. The lower the value of the economic sustainability indicator is, the more resilient the industry or individual enterprise is to the changes in the market conditions and the higher the margin of economic sustainability is [1].

Kononova I. V. [2] offers a comprehensive approach as the main approach to sustainability assessment, which is most ap- 
propriate for the dynamic analysis of the relationships between sustainability components.

Developing and analyzing new, more contemporary, adapted to modern conditions, non-traditional approaches to sustainability analysis is essential for strategic enterprise management.

We agree with O. M. Goncharenko's (2011, Diagnostics and assessment tools for sustainable enterprise development) conclusions regarding the main shortcomings of the existing methods of enterprise stability analysis:

- the variety of indicators recommended for the assessment of economic sustainability, the nature and content of which does not always meet the well-known requirements (principles) offered to the assessment systems (repeatability, level of detail, controversy, and others);

- the groundlessness and, as a result, the considerable variability of the normative values of the normalized indicators included in the system;

- modeling of integral indicators for the generalized complex estimation of economic stability with violation of the principles of mathematical modeling and without consideration of causation;

- separation from the existing information system accessible to external users of financial and economic information about the activity of the business entity.

According to L. S. Makukha (2008, Sustainable enterprise development: the current state of the problem), a significant drawback of the existing methodologies is that the assessment is made on the basis of historical data, and ensuring sustainable development requires not only an analysis of the current situation, but also the prediction of the situation regarding various aspects in the future.

Nitsenko V.S. and Havrysh V.I. researched the problems of stable development of the enterprises in Ukraine, including vertically integrated structure [3].

Bilan Y., Zos-Kior M., et al investigated the influences of social component in sustainable management of land resources [4].

Unsolved aspects of the problem. The scientists have paid insufficient attention to the development of a methodology for assessing the development of the enterprise on the basis of indicators in terms of components of the potential of the enterprise.

The purpose of the article is to improve the methodology for assessing the stability of the enterprise in terms of potential components and to determine the integral indicator of the stability of the enterprise as a whole.

Results. In the context of environmental uncertainty, the issue of improving the effectiveness of strategic management of enterprise development is urgent. In our opinion, the choice of strategy should be based on the assessment and forecasting of sustainability and intensity of enterprise development in terms of potential components.

In the economic literature, the term "sustainability" is more commonly used in the sense of "stability, equilibrium". Based on the theory of systems, stability is determined by the static state of the system, in the study of which changes in time characteristics of its essential properties can be neglected. Sustainable development is determined by the dynamic state of the system, which has many possible states that can change both continuously and discretely at certain points in time [5].

In our opinion, the identification of the above concepts is possible because the enterprise cannot function separately from the environment that surrounds it. In addition, both stability and sustainability of the enterprise imply a certain equilibrium of the enterprise, or the ability to return to it, overcoming the influence of external and internal factors, as well as implies economic growth, i.e. the ability to increase production and sales of products, improve the use of available resources and others.

The main factors affecting the sustainability of the enterprise are the following: changes in the system parameters, i.e. certain changes related to the components of the enterprise potential; the influence of environmental factors; breach of communication within the enterprise itself, change in its structure. Thus, the main goal of strategic management based on the sustainability of its development is to ensure the survival of the enterprise, its stability in the conditions of dynamism and uncertainty of the environment and development, achievement of the set goals.

Strategic management of an enterprise based on the sustainability of its development, should take into account changes occurring in the business environment, assess the dynamics and make assumptions about the future state of the enterprise, possible pessimistic and optimistic scenarios of its development. According to O. M. Goncharenko (2011), the alarm in this case is the output of enterprise performance indicators beyond the limit values, reaching them beyond the limit and loss of sustainability.

An enterprise sustainability management system as a component of strategic development management should perform the following functions:

- to forecast the changes in components of potential of the enterprise under the influence of factors of internal and external environment;

- to develop or adjust the enterprise development strategy based on the forecasts obtained in order to maintain the sustainable activity of the enterprise;

- to diagnose the enterprise at detection of stability threats of its functioning in the market in the future period;

- to make an appropriate changes at the enterprise in order to ensure the appropriate level of sustainability (stability).

Taking into consideration the complexity of the concept of sustainable development, it is very important to analyze it not on the basis of a single indicator, but on the basis of a certain number of indicators characterizing different components of the enterprise's potential.

In our opinion, the assessment of the development of the enterprise should be carried out on the basis of the assessment of potential, since the potential of the enterprise is the basis of its long-term development; it provides the transformation of the property to development in the development process. A comprehensive analysis of the enterprise's potential is carried out on the basis of a single information system of indicators. To determine the indicators is the most time-consuming stage, as the quality of the study and the evaluation obtained depends on it. The developed system of indicators should reflect the whole range of factors that contribute to or counteract the development of the enterprise.

We propose to evaluate the development of the company on the basis of indicators determined on the basis of a balanced system of indicators in terms of components of the potential of the enterprise. Let us look at each direction of a balanced scorecard from the dairy business standpoint:

- material and technical support (production and property potential): stockpile, material intensity, coefficient of depreciation of fixed assets, return on assets, coefficient of modernization, profitability of fixed assets, profitability of working capital, return on equity;

- development and training (labor potential): arms of employees with intangible assets, coefficient of provision of intellectual property, index of professional development, labor productivity, net income from sales of products per worker;

- finance (financial potential): profitability of the enterprise, the coefficient of financial stability, the coefficient of autonomy, the coefficient of financial leverage, the coefficient of long-term financial independence;

- clients (marketing potential): the share of the enterprise in the market, the ratio of the cost of sales and net income from the sale of products, the index of business reputation and image of the enterprise in the market, the consumer satisfaction index of the enterprise products; 
- business processes (organizational and managerial potential) ratio of turnover of equity, ratio of receivables, turnover ratio of assets, ratio of assets turnover, ratio of administrative costs and net income from the management of the product sales efficiency.

This system is the basis for a comprehensive study on the state of the enterprise's potential and serves as a tool for strategic management of the operation and development of the enterprise. The advantage of using the proposed system of indicators is the ability to form the information base of the study based on the statistical reporting of the enterprise.

The proposed system of indicators of stability of enterprise development allows evaluating all aspects of this complex phenomenon, including qualitative and structural ones [6]. It provides an increase in the level of validity of management decisions to ensure the development of the enterprise by taking into account all aspects of the enterprise and working out a strategy for its development.

For the mechanism of diagnostics of ensuring the stability of the enterprise development, the method for forming a complex of integral indicators of the level of development was used. O. V. Rayevneva (2006, Enterprise development management: methodology, mechanisms, models) implemented this method according to a number of stages. Let us look at some of them.

The formation of a family of integral indicators of retrospective level of development. At this stage, the calculation of integral indicators is based on the indicators justified in the previous stage by the components of the enterprise potential. form

Step 1. In general, the output matrix has the following

$$
X=\left[\begin{array}{ccccc}
x_{11} & \ldots & x_{1 j} & \ldots & x_{1 n} \\
x_{21} & \ldots & x_{2 j} & . & x_{2 n} \\
\cdot & . & . & . & . \\
x_{i 1} & \ldots & x_{i j} & \ldots & x_{i n} \\
. & . & . & . & . \\
x_{m 1} & \ldots & x_{m j} & \ldots & x_{m n}
\end{array}\right],
$$

where $n$ is the number of indicators $(j=1,2, \ldots, n) ; m$ is quantization period $(i=1,2, \ldots, m) ;\left(x_{i j}\right)$ is the value of this indicator at the $i^{\text {th }}$ moment.

The output is presented in time series.

Step 2. In the work [7], the previous list of substantiated indicators excludes those that do not affect the analyzed process. To do this, calculate the value of the coefficient of variation by the formula

$$
V_{j}=\frac{S_{j}}{\overline{x_{j}}} .
$$

Next, for each indicator, the inequality is checked $V_{j}<e$, where $e$ is the limit value, $e=0.1$.

If the value of the variation indicator is less than the limit value, then the indicators are considered quasi-constant and are excluded from further study. We suggest that the second step should be excluded from consideration, since the choice of benchmark in the future is independent of the number of indicators involved in the selection $[8,9]$.

The selected indicators have different dimensions, so the output matrix should be normalized by the formula

$$
Z_{i j}=\frac{x_{i j}}{S_{j}}
$$

where $x_{i j}$ is the value of $j$ indicator of the $i^{\text {th }}$ period; $S_{j}$ is standard deviation of the $j^{\text {th }}$ indicator.

Step 3. The clusterization of the original set of situations into homogeneous groups is considered. Euclidean distance (4) is considered as a measure of similarity of situations.

$$
d\left(Z_{j}, Z_{k}\right)=\sqrt{\sum_{i=1}^{m}\left(Z_{i j}-Z_{i k}\right)^{2}} .
$$

Step 4. The purpose of this step is to formulate a reference situation. If one considers the dynamics of each metric as a point in the $n$-dimensional metric space, then the coordinates of the reference point need to be determined, which requires the grouping of indicators into stimulants and stimulators. The stimulants include the indicators that have a positive effect on the analyzed process, the indicators-stimulants have opposite properties [10, 11]. We believe that in this case there is no single approach to the separation of stimulants and stimulants, it will depend on the values of the obtained indicators in the study period and their deviation from the normative value or will be determined by the impact of the indicators on the results of the enterprise.

When forming a benchmark $\left(P\left(Z_{1}, Z_{2}, \ldots, Z_{n}\right)\right)$ among indicators of stimulants, the indicators are selected with the maximum values of their coordinates, and among the indicators of the stimulators - with the minimum values of the formula

$$
Z_{i}=\left\{\begin{array}{ll}
\max _{i} Z_{i k}, & \text { if } k \in j \\
\min _{i} Z_{i k}, & \text { if } k \notin j
\end{array},\right.
$$

where $j$ is a set of stimulus indicators $(i=1,2, \ldots, m ; k=1,2, \ldots, n)$.

Step 5. The complex integrated assessment of the level of development of the analyzed process is calculated. Here is a mathematical derivation of an integral index (developed by the authors) that provides this estimate $[12,13]$. We denote the benchmark $d\left(d=\left(d_{1}, d_{2}, \ldots, d_{m}\right)\right)$.

Based on statistical considerations, we take the ratio of its change in a given period to its total change over all periods, that is, the value of the integral index of the system in the $k^{\text {th }}$ period $\frac{\left(d_{k}-\bar{d}\right)^{2}}{\sum_{i=1}^{m}\left(d_{i}-\bar{d}\right)^{2}}$.

We reduce this indicator to units of measure that is, as an integral indicator of the system in the period we consider the indicator determined by the formula

$$
\begin{aligned}
& I_{k}=\frac{\left|d_{k}-\bar{d}\right|}{\sqrt{\sum_{i=1}^{m}\left(d_{i}-\bar{d}\right)^{2}}} \\
& \text { The obvious inequalities } \frac{\left|d_{k}-\bar{d}\right|}{\sqrt{\sum_{i=1}^{m}\left(d_{k}-\bar{d}\right)^{2}}} \leq 1 \text { are as follows } \\
& \overline{\bar{d}-\sqrt{\sum_{i=1}^{m}\left(d_{i}-\bar{d}\right)^{2}}} \leq d_{k} \leq \bar{d}+\sqrt{\sum_{i=1}^{m}\left(d_{i}-\bar{d}\right)^{2}} \\
& \overline{\bar{d}-\sqrt{\sum_{i=1}^{m}\left(d_{i}-\bar{d}\right)^{2}}} \leq \\
& \overline{\bar{d}+\sqrt{\sum_{i=1}^{m}\left(d_{i}-\bar{d}\right)^{2}}} \leq \frac{d_{k}}{\bar{d}+\sqrt{\sum_{i=1}^{m}\left(d_{i}-\bar{d}\right)^{2}}} \leq 1
\end{aligned}
$$

The index of stability of the system of indicators in the $k^{\text {th }}$ period is taken as a value $I_{k}$

$$
I_{k}=1-\frac{d_{k}}{\bar{d}+\sqrt{\sum_{i=1}^{m}\left(d_{i}-\bar{d}\right)^{2}}}=1-\frac{d_{k}}{\bar{d}+\sqrt{m} \sqrt{\sum_{i=1}^{m} \frac{\left(d_{i}-\bar{d}\right)^{2}}{m}}} .
$$


Based on the inequality, the spectrum of change in the stability index is in the range from 0 to 1 .

The correctness of the choice of stability index by the formula is determined by the following circumstances: when the stability index goes to 0 , then the integral stability index goes to 1 .

That is, the coordinates or values of the indicator $d$ in each period go to (arithmetic mean) $\bar{d}$ to stable values. This allows explaining the essence of the stability of development in a separate group of indicators.

Rayevneva O. V. (2006) used the following value as the index of stability of the system of indicators

$$
I_{k}=1-\frac{d_{k}}{\bar{d}+2 \sqrt{\sum_{i=1}^{m} \frac{\left(d_{i}-\bar{d}\right)^{2}}{m}} .}
$$

The given value is the same as that given for $m=4$. The question arises: can the formula be universal for calculating the stability index of an enterprise?

It must be universal not only economically but also mathematically. That is, inequality $\frac{d_{k}}{\bar{d}+2 \sqrt{\sum_{i=1}^{m} \frac{\left(d_{i}-\bar{d}\right)^{2}}{m}}} \leq 1$ must take place for any integral sequence $d_{1}, d_{2}, \ldots, d_{m}$. The fact that it is false for all such sequences is illustrated by the following example. The following can be taken as a sequence: $d_{1}=0, d_{2}=$

$$
=0, \ldots, d_{m-1}=0, d_{m}=\frac{1}{m} \text {. }
$$

For this sequence of indicators, the stability index will look like this

$$
\begin{aligned}
& \frac{\frac{1}{m}}{\frac{1}{m^{2}}+2 \sqrt{\frac{\sum_{i=1}^{m}\left(\frac{1}{m^{2}}\right)^{2}+\left(\frac{1}{m}-\frac{1}{m^{2}}\right)^{2}}{m}}}= \\
& =\frac{\frac{1}{m}}{\frac{1}{m^{2}}+2 \sqrt{\frac{\frac{m-1}{m^{4}+\frac{(m-1)^{2}}{m^{4}}}}{m}}}=\frac{m}{1+2 \sqrt{\frac{m^{2}-m+2}{m}}} .
\end{aligned}
$$

The corresponding inequality $\frac{d_{k}}{\bar{d}+2 \sqrt{\sum_{i=1}^{m} \frac{\left(d_{i}-\bar{d}\right)^{2}}{m}}} \leq 1$, that is, the inequality $\frac{m}{1+2 \sqrt{\frac{m^{2}-m+2}{m}}} \leq 1$ holds only for $m \leq 6$.

Thus, the formula for determining the stability index $\frac{d_{k}}{\bar{d}+2 \sqrt{\sum_{i=1}^{m} \frac{\left(d_{i}-\bar{d}\right)^{2}}{m}}}$ cannot be accepted.

The methodology for building a stability index for a particular group of enterprise indicators can be taken as a basis for building a stability index for the development of the entire enterprise, as well as its industry $[14,15]$.

The enterprise development stability index is calculated on the basis of the development stability indices $I_{k j}-j-$ the indicator in the $k^{\text {th }}$ period by the components of the enterprise potential, all of which in this case are stimulus indicators. Among these indicators the reference indicator $\left(I_{e}\right)$ is selected, $I_{e_{k}}$ is its value in the $k^{\text {th }}$ period. The distances from the benchmark to the indicators are determined by the formula

$$
d_{Z_{k}}=\sqrt{\sum_{i=1}^{m}\left(I_{k j}-I_{e j}\right)^{2}}
$$

Enterprise stability index $\left(I_{Z}\right)$ in each period is

$$
\begin{gathered}
I_{Z_{k}}=1-\frac{d_{Z_{k}}}{\overline{d_{Z}}+\sqrt{m}} \\
I_{Z_{k}}=1-\frac{d_{Z_{k}}}{\overline{d_{Z}}+\sqrt{m} * \sqrt{\sum_{i=1}^{m}\left(d_{Z_{i}}-\overline{d_{Z}}\right)^{2}}} .
\end{gathered}
$$

We agree with existing studies on the distribution of the levels of the enterprises' development in accordance with the obtained values of the stability index development (Table).

Absolute stability of enterprise development: operation of the enterprise is characterized by a state of balanced equilibrium on all assessment indicators, resulting in the most efficient use of all available resources, receiving a significant income from sales of products, which cover production and other costs, and the possibility of expansion or modernization of production, changing the assortment of the production structure, introduction of innovative development strategies and, as a consequence, the strengthening of the company position in the market; the company holds a stable personnel policy, which provides a high level of remuneration [16, 17].

A stable state is reflected mainly in high values of the indicators of the evaluation components of strategic stability, however, there appear temporary difficulties (industrial, supply issues), overcoming of which requires additional resources (financial, material, labor), which in turn limits the ability of enterprises to modernize the production, manufacture new products and the like [18, 19].

Relatively stable state affirms that the company operates consistently, it can result in average industry performance evaluation component of strategic stability; difficulties associated with the production and retention conquered earlier segments of the sales market, due to both exogenous and endogenous factors of influence on the functioning of the enterprise as a whole [20].

The unstable state of the enterprise: erratic production and poor demand, untimely logistical support, breach of solvency, poor psychological climate in the team, reduced productivity. But there is still a possibility of establishing the balance due to the replenishment of sources of equity and increase in working capital and additional long-term loans and borrowings.

The crisis signifies that the company is unstable with temporary shutdowns, which, as a result, is marked as a common condition that is close to bankruptcy; personnel policy at the enterprise is unstable, resulting in low productivity, high turnover of qualified staff; the needs of consumers are satisfied, not in full; strategic management is ineffective.

In the calculation of the overall enterprise development stability index, the methodology for determining the develop-

\section{Table}

Estimations of stability of the enterprise development

\begin{tabular}{|c|l|}
\hline $\begin{array}{c}\text { The value of the stability } \\
\text { index development }\end{array}$ & Classification of level of development \\
\hline $0.8 \leq I_{z} \leq 1$ & Absolutely stable state \\
\hline $0.6 \leq I_{z} \leq 0.79$ & Stable state \\
\hline $0.4 \leq I_{z} \leq 0.59$ & Relatively stable state \\
\hline $0.2 \leq I_{z} \leq 0.39$ & Unstable state \\
\hline $0 \leq I_{z} \leq 0.19$ & Crisis \\
\hline
\end{tabular}


ment stability indices in terms of the components of the enterprise potential was used and improved. The proposed methodology for calculating the stability of the enterprise development can also be used to assess the stability of the development of the industry.

Conclusions. As a result of the research, proposals were made to improve the methodology for assessing the stability of the enterprise in terms of potential components, and a method was proposed for calculating the integral index of stability of the enterprise as a whole. Further research is related to the development of tools for assessing the intensity of enterprise development and forecasting.

\section{References.}

1. Nakonechna, O.S. (2015). Methodical approaches to assessing the economic stability of industrial enterprises. Investytsii: praktyka ta dosvid, 6, 47-53.

2. Kononova, I. V. (2016). Directions for ensuring the functioning of the construction company. Skhidna Yevropa: ekonomika, biznes ta upravlinnia, 1(01), 60-64.

3. Nitsenko, V. S., \& Havrysh, V. I. (2016). Enhancing the stability of a vertically integrated agro-industrial companies in the conditions of uncertainty. Actual problems of economics, 10(184), 167-172.

4. Bilan, Y., Zos-Kior, M., Nitsenko, V., Sinelnikau, U., \& Ilin, V. (2017). Social component in sustainable management of land resources. Journal of Security and Sustainability, 7(2), 107-120. https://doi.org/10.9770/jssi.2017.7.2(9).

5. Latysheva, O., Rovenska, V., Smyrnova, I., Nitsenko, V., Balezentis, T., \& Streimikiene, D. (2020). Management of the sustainable development of machine-building enterprises: a sustainable development space approach. Journal of Enterprise Information Management. https://doi.org/10.1108/JEIM-122019-0419.

6. Baharun, R., Jing Mi, T., Streimikiene, D., Mardani, A., Shakeel, J., \& Nitsenko, V. (2019). Innovation in healthcare performance among private brand's healthcare services in small and medium-sized enterprises (SMEs). Acta Polytechnica Hungarica, 16(5), 151-172. https://doi.org/10.12700/APH.16.5.2019.5.9.

7. Gusieva, O. Yu. (2019). Theoretical and practical approaches to substantiation of tools of strategic management of sustainable development of telecommunication enterprise. Ekonomika. Menedzhment. Biznes, 2, 126-135.

8. Barybina, Ya. O. (2017). Management of sustainable development in conditions of uncertainty. Naukovyi Visnyk Poltavskoho Universytetu Ekonomiky i torhivli, 3(81), 74-79.

9. Bilan, Y., Nitsenko, V., Ushkarenko, I., Chmut, A., \& Sharapa, O. (2017). Outsourcing in international economic relations. Montenegrin Journal of Economics, 13(3), 175-185. https://doi.org/10.14254/1800-5845/2017.13-3.14.

10. Svyrydenko, D., \& Stovpets, O. (2020). Cultural and Economic Strategies of Modern China: In Search of the Cooperation Models across the Global World. Future Human Image, 13, 102-112. https://doi.org/10.29202/fhi/13/11.

11. Nitsenko, V., Nyenno, I., Kryukova, I., Kalyna, T., \& Plotnikova, M. (2017). Business model for a sea commercial port as a way to reach sustainable development goals. Journal of Security and Sustainability Issues, 7(1), 155-166. https://doi. org/10.9770/issi.2017.7.1(13).

12. Filipishyn, I.V. (2015). Industrial development management: approaches and methodology. Teoretychni i praktychni aspekty ekonomiky ta intelektualnoii vlasnosti, 2(12), T. 3, 39-44. 13. Filipchuk, V. (2019). Information and Digital Toolset in a Fight against Liberal Democracy and Values of Open Society. Ukrainian Policymaker, 5, 34-43. https://doi.org/10.29202/ $\underline{\mathrm{up} / 5 / 4}$.

14. Wysmułek, J., Hełdak, M., \& Kucher, A. (2020). The Analysis of Green Areas' Accessibility in Comparison with Statistical Data in Poland. International Journal of Environmental Research and Public Health, 17, 4492. https://doi. org/10.3390/ijerph17124492.
15. Piletsky, E. (2019). Consciousness and Unconsciousness of Artificial Intelligence. Future Human Image, 11, 66-71. https://doi.org/10.29202/fhi/11/7.

16. Tarasiuk, H. M., Kovalchuk, V. H., \& Sotnyk, A. A. (2020). Complex forecasting in the system of strategic diagnostics of enterprise's potential. Financial and credit activity: problems of theory and practice, 2(33), 358-366. https://doi.org/10.18371/ fcaptp.v2i33.207089/.

17. Kucher, A., Anisimova, O., \& Heldak, M. (2019). Efficiency of land reclamation projects: New approach to assessment for sustainable soil management. Journal of Environmental Management and Tourism, 10(7), 1568-1582. https://doi. org/10.14505//jemt.10.7(39).14.

18. Shvydanenko, G. O. (2015). Enterprise development: strategic intentions, risks and effectiveness: monograph. Kyiv: KNEU. 19. Melnyk, T. (2018). Ukraine and Its Future in a Globalised International Community. Ukrainian Policymaker, 3, 17-28. https://doi.org/10.29202/up/3/3.

20. Nitsenko, V., Mardani, A., Kuksa, I., \& Sudarkina, L. (2018). Additional opportunities of systematization the marketing research for resource conservation practice. Management Theory and Studies for Rural Business and Infrastructure Development, 40(3), 361-368. https://doi.org/10.15544/ mts.2018.34.

\section{Методичні аспекти оцінки стабільності розвитку підприємств}

\section{Г. М. Тарасюк ${ }^{1}$, О. П. Пащенко ${ }^{1}$ О. В. Мілінчук ${ }^{1}$, A. О. Чагайда ${ }^{1}$, O. В. Сєнько}

1 - Державний університет «Житомирська політехніка», м. Житомир, Україна, e-mail: galinatar@ukr.net

2 - Національний університет «Одеська морська академія», м. Одеса, Україна, e-mail: o.sienko@onma.edu.ua

Мета. Уточнення визначення понять «стабільність і стійкість підприємства». Визначення основних чинників, що здійснюють вплив на стійкість підприємства. Формування системи індикаторів оцінки стабільності розвитку підприємства та удосконалення методики цієї оцінки на основі збалансованої системи показників.

Методика. В основу дослідження покладені методи аналізу й синтезу, методи порівняння, абсолютних і відносних величин, абстрагування, аналогії, розрахунковоконструктивний. Для оцінки стабільності розвитку підприємств, при прогнозуванні можливих алгоритмів їх розвитку - методи групування, кореляційно-регресивного аналізу, дисперсії.

Результати. У роботі уточнено визначення понять «стабільність і стійкість підприємства». На думку авторів, можливе ототожнення наведених понять, оскільки підприємство не може функціонувати окремо від середовища діяльності. Крім цього, і стабільність, і стійкість розвитку підприємства передбачають певний рівноважний його стан, або можливість повернення до нього, економічне зростання, тобто здатність нарощувати обсяги виробництва й реалізації продукції, підвищення ефективності використання наявних ресурсів та ін. Визначені основні чинники, що здійснюють вплив на стійкість підприємства, зокрема: зміна параметрів системи, тобто певні зміни, що пов'язані зі складовими потенціалу підприємства; вплив факторів зовнішнього середовища; порушення зв'язків у самому підприємстві, зміна його структури. Стратегічне управління підприємством на основі стійкості його розвитку повинне враховувати зміни, що відбуваються в бізнес-середовищі, оцінювати динаміку та робити припущення відносно майбутнього стану підприємства, можливих песимістичних та оптимістичних сценаріїв його розвитку. Авторами запропоновано здійснювати оцінку розвитку підприємства на 
основі оцінки потенціалу, оскільки потенціал підприємства виступає основою його довготривалого розвитку. Сформована система індикаторів оцінки стабільності розвитку на основі збалансованої системи показників у розрізі складових потенціалу підприємства. Розроблені пропозиції щодо вдосконалення методики оцінки стабільності розвитку підприємства, запропонована методика оцінки стабільності розвитку підприємства в цілому.

Наукова новизна. Удосконалена методика визначення інтегральних індексів стабільності розвитку підприємств, що, на відміну від існуючих, базується на оцінці індикаторів розвитку в розрізі складових потенціалу; запропонована методика розрахунку інтегрального індексу стабільності розвитку підприємства в цілому.

Практична значимість. Методичні засади оцінки стабільності розвитку промислового підприємства та результати дослідження можуть бути використані для подальших наукових розробок у даному напрямі, а також у практичній діяльності промислових підприємств для оцінки інтенсивності їх розвитку. Оцінка стабільності розвитку підприємства на основі сформованої системи індикаторів забезпечує підвищення рівня обгрунтованості управлінських рішень із забезпечення його розвитку шляхом урахування всіх аспектів діяльності та розробки стратегії його розвитку.

Ключові слова: промислове підприємство, стабільність розвитку, стратегія розвитку

\section{Методические аспекты оценки стабильности развития предприятий}

\section{Г. Н. Тарасюк ${ }^{1}$ О. П. Пащенко ${ }^{1}$ О. В. Милинчук ${ }^{1}$, А. О. Чагайда ${ }^{1}$, Е. В. Сенько ${ }^{2}$}

1 - Государственный университет «Житомирская политехника», г. Житомир, Украина, e-mail: galinatar@ukr.net 2 - Национальный университет «Одесская морская академия», г. Одесса, Украина, e-mail: o.sienko@onma.edu.ua

Цель. Уточнение определения понятий «стабильность и устойчивость предприятия». Определение основных факторов, оказывающих влияние на устойчивость предприятия. Формирование системы индикаторов оценки стабильности развития предприятия и совершенствование методики этой оценки на основе сбалансированной системы показателей.

Методика. В основу исследования положены методы анализа и синтеза, методы сравнения, абсолютных и относительных величин, абстрагирования, аналогии, расчетно-конструктивный. Для оценки стабильности развития предприятий, при прогнозировании возможных алгоритмов их развития - методы группировки, корреляционно-регрессионного анализа, дисперсии.
Результаты. В работе уточнено определение понятий «стабильность и устойчивость предприятия». По мнению авторов, возможно отождествление приведенных понятий, поскольку предприятие не может функционировать отдельно от среды деятельности. Кроме этого, и стабильность, и устойчивость развития предприятия предусматривают определенное равновесное его состояние, или возможность возврата к нему, экономический рост, то есть способность наращивать объемы производства и реализации продукции, повышение эффективности использования имеющихся ресурсов и др. Определены основные факторы, которые оказывают влияние на устойчивость предприятия, в частности: изменение параметров системы, то есть определенные изменения, связанные с составляющими потенциала предприятия; влияние факторов внешней среды; нарушение связей в самом предприятии, изменение его структуры. Стратегическое управление предприятием на основе устойчивости его развития должно учитывать изменения, происходящие в бизнес-среде, оценивать динамику и предположения относительно будущего состояния предприятия, возможных пессимистичных и оптимистичных сценариев его развития.Авторами предложено осуществлять оценку развития предприятия на основе оценки потенциала, поскольку потенциал предприятия выступает основой его долговременного развития. Сформирована система индикаторов оценки стабильности развития на основе сбалансированной системы показателей в разрезе составляющих потенциала предприятия. Разработаны предложения по совершенствованию методики оценки стабильности развития предприятия, предложена методика оценки стабильности развития предприятия в целом.

Научная новизна. Усовершенствована методика определения интегральных индексов стабильности развития предприятий, которая, в отличие от существующих, базируется на оценке индикаторов развития в разрезе составляющих потенциала; предложена методика расчета интегрального индекса стабильности развития предприятия в целом.

Практическая значимость. Методические основы оценки стабильности развития промышленного предприятия и результаты исследования могут быть использованы для дальнейших научных разработок в данном направлении, а также в практической деятельности промышленных предприятий для оценки интенсивности их развития. Оценка стабильности развития предприятия на основе сложившейся системы индикаторов обеспечивает повышение уровня обоснованности управленческих решений по обеспечению его развития путем учета всех аспектов деятельности и разработки стратегии его развития.

Ключевые слова: промышленное предприятие, стабильность развития, стратегия развития

Recommended for publication by O.I. Gonchar, Doctor of Economic Sciences. The manuscript was submitted 18.03.20. 